HANNA KUBIAK

ORCID 0000-0002-1795-8528

Uniwersytet im. Adama Mickiewicza

$w$ Poznaniu

\title{
NARRACJE RODZICÓW MŁODZIEŻY Z ZABURZENIAMI PSYCHICZNYMI
}

AвSTRACt. Kubiak Hanna, Narracje rodziców młodzieży z zaburzeniami psychicznymi [Adolescents with Mental Disorders in their Parents Narratives]. Studia Edukacyjne nr 56, 2020, Poznań 2020, pp. 167184. Adam Mickiewicz University Press. ISSN 1233-6688. DOI: 10.14746/ se.2020.56.9

The text is devoted to analyzing the narrative of parents of adolescents with mental disorders. Families in which young people with mental disorders are brought up are in a specifically difficult situation. Their basic assumptions regarding the safety of their existence are being undermined. They experience different emotions, usually to a large extent. Parents undergoing this special experience were offered to participate in a support group conducted with assumptions of existential and narrative psychology. The purpose of this text is to present and discuss research results, focusing on the analysis of parental narratives obtained in the described context. They concerned, among others, the adoption of psychiatric diagnosis, the relationship between parents and children, and parental identity.

Key words: narratives, adolescents with mental disorders, parents, developmental group

Niniejszy tekst poświęcony jest narracjom rodziców młodzieży z zaburzeniami psychicznymi odnośnie sposobu, w jaki przeżywają swoje rodzicielstwo naznaczone doświadczeniem zaburzenia psychicznego u dziecka.

Pojęcie narracji można wyjaśniać, po pierwsze, nawiązując do tytułu książki prof. J. Trzebińskiego, jako sposób rozumienia świata ${ }^{1}$, po drugie jako wytwór aktywności ludzkiego umysłu, po trzecie wreszcie - odnosząc się do obu interpretacji, akcentując znaczenie narracji, zwłaszcza o szczególnym charakterze, dla procesu terapeutycznego ${ }^{2}$. W niniejszym tekście pojęcie narracji stosuje się we wszystkich tych kontekstach.

${ }^{1}$ J. Trzebiński (red.), Narracja jako sposób rozumienia świata, Gdańsk 2002.

${ }^{2}$ Nie wyczerpuje to wszystkich znaczeń narracji - np. E. Soroko, Narracja jako tekst kultury czy sposób komunikowania się, Poznań 2007 (praca doktorska). 


\section{Rodzice młodzieży z zaburzeniami psychicznymi}

Dojrzewanie fizyczne rozpoczyna wędrówkę młodych ludzi ku dorosłości ${ }^{3}$. Rozwój umysłu i świata relacji, który następuje w tym czasie, ma umożliwić młodemu człowiekowi sprawne funkcjonowanie jako osobie dojrzałej. Wyraża się to wyznaczeniem przez podmiot kierunku życia, umiejętnością wzięcia odpowiedzialności za siebie i innych, osiągnięciem niezależności jakkolwiek z uwagi na społeczną naturę człowieka zawsze będzie to niezależność względna - oraz wolnością w podejmowaniu życiowych wyborów i siłą do ich realizacji ${ }^{4}$. Ten proces „dorastania ku dorosłości” w społecznym przekonaniu jest trudny zarówno dla przeżywającej go młodzieży, jak i dla towarzyszących jej rodziców, nauczycieli ${ }^{5}$. W szczególnie trudnej sytuacji znajdują się rodzice adolescentów z diagnozą psychiatryczną ${ }^{6}$. Diagnoza ta zazwyczaj ich zaskakuje, zmienia bieg życia, wymusza indywidualną odpowiedź na często niezrozumiałe zachowania dzieci. Są zmuszeni skonfrontować się $\mathrm{z}$ nową, niechcianą sytuacją ${ }^{7}$, doświadczając przy tym lęku, poczucia winy, wstydu ${ }^{8}$. W tych okolicznościach szczególnie trudne staje się dla rodziców rozwiązywanie dylematów właściwych rodzinom z dorastającymi dziećmi, a dotyczących poruszania się na kontinuum pobłażliwość-kontrola, wspieranie-autonomia, czy interpretowanie trudnych zachowań (normalizowanie „patologicznych" versus patologizowanie „normalnych") ${ }^{9}$.

Rodzice często zgłaszają ${ }^{10}$ brak zrozumienia sytuacji swojej rodziny; mają potrzebę „poukładania” świata na nowo, dostrzeżenia swojej roli w zdrowieniu dziecka i/lub w towarzyszeniu mu w zaburzeniu. Wśród wielu podejść terapeutycznych można wskazać terapię narracyjną jako tę, która potrafi odpowiedzieć na te potrzeby.

\section{Podstawowe założenia podejścia narracyjnego}

Człowiek usiłuje zrozumieć świat, w przestrzeni którego przebiega jego życie. Owo rozumienie obejmuje procesy interpretowania zdarzeń, nada-

${ }^{3}$ A. Oleszkiewicz, A. Senejko, Psychologia dorastania, Warszawa 2013.

${ }^{4}$ P. Oleś, Psychologia człowieka dorosłego, Warszawa 2011.

${ }^{5}$ H. Kubiak, Problemy rodziców adolescentów z zaburzeniami psychicznymi, [w:] W trosce o macierzyństwo, red. E. Włodarczyk, Poznań 2017, s. 83-94.

${ }^{6} \mathrm{H}$. Kubiak, M. Zięba, Grupa rozwoju osobistego dla młodzieży z zaburzeniami psychicznymi sprawozdanie z zajęć, Studia Edukacyjne, 2015, 36, s. 327-345.

${ }^{7}$ H. Kubiak, Edukacja emocjonalna adolescentów - program profilaktyczny ukierunkowany na wspomaganie zdrowia psychicznego adolescentów, Kultura - Społeczeństwo - Edukacja, 2016, 2(10), s. $111-123$.

${ }^{8}$ H .Kubiak, Problemy rodziców adolescentów, s. 83-94.

${ }_{9}$ A. Miller, J. Rathus, M. Linehan, Dialektyczna terapia behawioralna nastolatków z tendencjami samobójczymi, przekł. J. Okuniewski, Kraków 2011.

${ }^{10}$ H. Kubiak, M. Zięba, Grupa rozwoju osobistego, s. 327-345. 
wania im znaczeń. Uznanie takiego subiektywnego sposobu poznawania rzeczywistości oznacza zarazem przyjęcie założenia, że istnieje wiele możliwych dróg rozumienia tego, co człowieka spotyka. Jednym z narzędzi tego zrozumienia jest tworzenie historii, w literaturze przedmiotu określanych jako narracje ${ }^{11}$.

Narracje, czyli umysłowe formy rozumienia świata strukturalizują nasze doświadczenia w kategoriach ludzkich intencji, oraz problemów, które wynikają z komplikacji na drodze urzeczywistniania tych intencji ${ }^{12}$.

Narracje służą porządkowaniu pojedynczych ciągów zdarzeń w ramach szerszego kontekstu ludzkiego życia, mogą się zmieniać wraz z napływającymi doświadczeniami ${ }^{13}$. Tak naprawdę historia narracji człowieka odzwierciedla historię jego rozwoju ${ }^{14}$. Jak wskazuje Trzebiński,

Narracje jako formy rozumienia rzeczywistości posiadają uniwersalną, podstawową strukturę: bohater $z$ określonymi intencjami napotyka na trudności, które w wyniku zdarzeń toczących się wokół zagrożonych celów zostaja, bądź nie zostają przezwyciężone $e^{15}$.

Istotą narracyjności jest intencjonalnośćc ${ }^{16}$, która zakłada świadomą ingerencję człowieka w bieg zdarzeń. Ludzkie przymioty, zalety, umiejętności, zaangażowanie i wartości mogą stać się orężem równoważącym znaczenie doświadczanych przeszkód i przeżywanych nieszczęśćc ${ }^{17}$. Osoba organizuje treści na podstawie tak zwanych schematów narracyjnych ${ }^{18}$, modelujących treści, a zawierających pewne elementy wyróżniające go spośród innych rodzajów schematów. Zatem, na ten schemat składają się: (a) bohaterzy narracji, (b) ich wartości, intencje i plany działania, (c) komplikacje i utrudnienia oraz (d) uwarunkowania i szanse ich przezwyciężenia ${ }^{19}$.

${ }^{11}$ Tamże.

12 J. Trzebiński (red.), Narracja jako sposób rozumienia świata, s. 21; J. Bruner, Actual minds, possible worlds, Cambridge 1986; G. Howard, Culture tales: A narrative approach to thinking, cross-cultural psychology, and psycho therapy, American Psychologist, 19991, 46(3), s. 187-197; D. McAdams, Personal narratives and the life story, [w:] Handbook of personality: Theory and research, (II wyd.), red. L. Pervin, O. John, Nowy Jork 1999; T. Sarbin (red.), Narrative psychology: The storied nature of human conduct, New York 1986.

${ }^{13}$ D.P. McAdams, The Psychology of Life Stories, Review of General Psychology, 2001, 2, s. 100-122.

${ }^{14}$ Sprawia to, że reinterpretacji należy poddać pojęcie tożsamości, skoro zmieniają się narracje, a także rozumienie bohatera.

${ }^{15} \mathrm{~J}$. Trzebiński (red.), Narracja jako sposób rozumienia świata, s. 17-42.

${ }_{16} \mathrm{~J}$. Cieciuch, Między przedmiotem a metodą. Wątpliwości związane z koncepcja tożsamości narracyjnej McAdamsa, [w:] Psychologia narracyjna, red. E. Dryll, A Cierpka, Warszawa 2011, s. 111-131.

${ }_{17}$ M. White, D. Epston, Narrative means to therapeutic ends, WW Norton \& Company, 1990.

18 J. Trzebiński (red.), Narracja jako sposób rozumienia świata, s. 17-42.

19 Tamże. 
Kiedy przyjmujemy podejście narracyjne, domyślnie zgadzamy się na pewne założenia.

1. O tworzeniu się subiektywnych znaczeń - co oznacza zgodę na to, że historia jest tworzona $\mathrm{w}$ procesie poznawania poprzez podmiot, a nie jedynie odkrywana, istniejąc niezależnie od tego podmiotu. Proces ów ma charakter subiektywny ${ }^{20}$. To założenie o świecie nie zewnętrznym wobec podmiotu, lecz „,stającym się" w jego umyśle wywodzić można z filozofii Heideggerowskiej i jego następców.

2. O wartości znaczeń - osoba przeżywa wiele zdarzeń, na które nie zawsze ma wpływ, jednak może zadecydować o nadawanym im przez siebie sensie $^{21}$. Z punktu widzenia jakości życia ów sens ma znaczenie podstawowe. Ta prawda może okazać się szczególnie ważna w sytuacji, na przebieg której mamy ograniczony wpływ. Zawsze jednak istnieje możliwość nadania sensu czemuś, co wydaje się go pozbawione.

3. Zasada wielości narracji - każdy człowiek tworzy własną, unikalną historię w związku z jakimś wydarzeniem. Co więcej, ta sama osoba zmieniając się, rozwijając, przeformułowując doświadczenie $w$ miarę napływu nowych, ma możność konstruowania kolejnych narracji w związku z jednym wydarzeniem. „Każda refleksja nad człowiekiem musi uwzględniać jej czasowość”22. Co ważne, podmiot może zmieniać w swoim umyśle nie tylko sens narracji, ale i jej przebieg ${ }^{23}$.

Jak wskazuje P. Oleś, fakt, że interpretacja doświadczeń implikuje wiele możliwości i konkurujących punktów widzenia, stanowi wyzwanie dla Ja rozumianego jako struktura integrująca doświadczenie ${ }^{24}$.

4. O społecznym konstruowaniu narracji - autor narracji żyje w określonym społeczeństwie, miejscu, czasie i kontekście, co wyznacza jego możliwości interpretacyjne $e^{25}$, dostarcza mu narzędzi rozumienia rzeczywistości. Najistotniejsze ludzkie doświadczenia są „przepracowane” i opowiadane po wielokroć przez wiele osób, często z zachowaniem zasady odnoszenia się do mitologii, literatury, sztuki ${ }^{26}$. W toku tych odniesień trwa proces konstruowania osobistych narracji wywodzących się, zmieniających, pozostających w związku z narracją społeczną. Ta perspektywa odnosi się do społecznego kontekstu tworzenia narracji $\mathrm{w}$ rozumieniu zanurzenia $\mathrm{w}$ kulturze, jej symbolice $\mathrm{i}$ ramach.

${ }^{20}$ O dwóch postawach w poznawaniu świata np. w: N. Denzin, Y. Lincoln, Metody badań jakościowych, przekł. K. Podemski, Warszawa 2009.

${ }^{21}$ V. Frankl, Człowiek w poszukiwaniu sensu, przekł. A. Wolnicka, Warszawa 2011.

${ }^{22}$ J. Cieciuch, Między przedmiotem a metoda, s. 119.

${ }^{23}$ D.P. McAdams, The Psychology of Life Stories, s. 100-122; także M. Zięba w: H. Kubiak, M. Zięba, Grupa rozwoju osobistego.

${ }_{24}^{24}$ P. Oleś, Dialogowe Ja: zarys teorii, inspiracje badawcze, ciekawsze wyniki, [w:] Dialog z samym soba, red. P. Oleś, M. Puchalska-Wasyl, Warszawa 2011, s. 143-165.

${ }^{25}$ M. White, D. Epston, Narrative means to therapeutic ends.

${ }^{26}$ J. Trzebiński (red.), Narracja jako sposób rozumienia świata, s. 17-42. 
Można jeszcze odnieść się do społecznego kontekstu narracji z perspektywy konkretnych zdarzeń i ludzi. Jak wskazuje J. Trzebiński ${ }^{27}$, obecność słuchacza wpływa na treść narracji, ponieważ sama obecność drugiej osoby modyfikuje historię. Według H. Hermansa ${ }^{28}$, opowiadanie historii implikuje słuchacza - prawdziwego lub wyobrażonego - którego obecność modyfikuje historię, a przedtem motywuje autora do opowiadania, a zatem $\mathrm{w}$ pewnym sensie również go tworzy ${ }^{29}$.

5. Jezzyk jako narzędzie konstruowania narracji - język nie tylko opisuje rzeczywistość, ale również ją tworzy. Może również służyć zmianie historii, która oznacza zmianę wewnętrznej rzeczywistości narratora (por. założenie 3$)^{30}$. Jak wskazywał Wittgenstein, granice naszego języka wyznaczają granice naszego świata, jednak oznacza to, że rozwijanie „dialogującego języka” może stanowić narzędzie interwencji wspierającej rozwój lub terapeutycznej.

\section{Badanie}

Cele badań sformułowano $\mathrm{w}$ odniesieniu do dwóch grup zagadnień. Pierwsza związana była z treściami dotyczącymi rodzicielstwa, przeżywania zaburzeń psychicznych u adolescenta, zasobów i ograniczeń rodziny w mierzeniu się z tym problemem. Próbowano odpowiedzieć między innymi na następujące pytania: $w$ jaki sposób rodzice młodzieży ze zdiagnozowanymi zaburzeniami psychicznymi przeżywają to doświadczenie, to jest, czy i jaki sens mu nadają, w jaki sposób wpisują to doświadczenie w historię własną i całej rodziny, czy dokonuje się na skutek przeżyć związanych z zaburzeniami psychicznymi adolescentów zmiana w tożsamości rodzicielskiej ich matek oraz ojców. Druga grupa zagadnień odnosiła się do roli grupy wspomagającej rozwój w przeżywaniu tego doświadczenia ${ }^{31}$. Planowano odpowiedzieć na pytania dotyczące znaczenia grupy w procesie zmagania się z zaburzeniem psychicznym adolescenta.

27 Tamże.

${ }^{28}$ H. Hermans, Self-Narrative as Meaning Construction: The Dynamics ol Selflnvestigation, Journal of Clinical Psychology, 1999, 55(10), s. 1193-1211; także w: E. Soroko, Poziom autonarracyjności wypowiedzi i użyteczność wybranych sposobów ich generowania, Poznań 2007 (praca doktorska).

29 Założenie to było szczególnie istotne w kontekście planowania badań przeprowadzonych w grupie, kiedy to istnieje rzeczywistość społeczna dzielona pomiędzy wieloma podmiotami.

30 Rodzi to konieczność zredefiniowania pojęcia tożsamości, której trudno przypisać stałe własności, chyba że lokują się one w możliwości/gotowości do zmieniania się - por. K. Rosner, Narracja, tożsamość i czas, Kraków 2003.

31 Rolę grupy wsparcia, jak ją pojmowano w tych badaniach, opisano szerzej w artykule: H. Kubiak, M. Zięba, Grupa rozwoju osobistego, s. 327-345. 
Zaplanowano, że projekt będzie realizowany w formie dziesięciu 90-minutowych spotkań, cotygodniowych, z wyjątkiem dni ustawowo wolnych od pracy. W programie uczestniczyło ośmioro ${ }^{32}$ rodziców, przy czym osoby te same zgłaszały się do prowadzących. Informacje o projekcie zostawiono na Oddziale Psychiatrycznym Uniwersytetu Medycznego przy ul. Szpitalnej w Poznaniu, jak również umieszczono w Internecie. Na wstępnej rozmowie omówiono cele i zasady spotkań, podano także kryteria umożliwiające uczestniczenie w projekcie, to jest wiek młodej osoby (syna lub córki uczestnika grupy) ze zdiagnozowanym przez lekarza psychiatrę zaburzeniem (późna adolescencja), brak diagnozy o zaburzeniu psychicznym u rodziców ${ }^{33}$, zgoda na nagrywanie i poddanie wyników analizie, a następnie publikacji.

Zawiązana grupa stanowiła charakter zamknięty, co miało sprzyjać zaufaniu między uczestnikami, budować gotowość do otwierania się, wspierania. Obserwacje potwierdziły, że takie czynniki w grupie zaistniały. W istocie, przechodziła ona przez wszystkie fazy dla grup charakterystyczne ${ }^{34}$.

Na większości spotkań ${ }^{35}$ osoba prowadząca zapraszała uczestników do osobistych opowiadań z użyciem narracyjnego bodźca. Tę część zajęć nagrywano. Pozostały czas wykorzystywany był "poza mikrofonem”; omawiano wówczas bieżącą sytuację, emocje rodziców, którzy wzajemnie się wspierali, podawali pomysły dotyczące reakcji na pojawiające się trudne zachowania dzieci. Na zajęciach prowadzono również psychoedukację, dotyczącą adolescencji, zaburzeń występujących w tym okresie, sytuacji emocjonalnej rodziców. Te fragmenty spotkań nie były rejestrowane ani analizowane. Służyły celom pozabadawczym, choć emocje, które wówczas dzielono, współpraca i wsparcie, które okazywano, niewątpliwie mogły wpływać na łatwość i sposób reagowania na bodźce narracyjne i uruchamiane treści w kolejnych tygodniach (zazwyczaj nagrywane części zajęć miały miejsce w pierwszej ich połowie).

Narracje powstałe na skutek reakcji na narracyjne bodźce zostały po nagraniu poddane transkrypcji i w tej formie analizowane.

Na cele przedstawianych badań dokonano operacjonalizacji narracyjności, czyli założono, że aby wypowiedź zakwalifikować jako narrację podda-

32 Zajęcia rozpoczęło dziewięć osób, ale jedna, po dwóch spotkaniach, musiała zrezygnować z powodu nagłej sytuacji losowej.

${ }_{33}$ Obecnie nie jestem przekonana co do zasadności tego warunku: część osób spełniłaby kryteria, np. zaburzeń nastroju, i wymóg ten nie sprawił, że w grupie nie uczestniczyły osoby z zaburzeniami: jedynie te, które nie miały w tamtym czasie diagnozy (lub, być może, ją zataiły). Warunek ten wynikał wówczas nie z dążenia do objęcia badaniami osób o wysokim stopniu podobieństwa (takiego dążenia nie było), a do możliwości uczestniczenia akurat w grupowej formie wsparcia.

${ }^{34}$ I. Yalom, M. Leszcz, Psychoterapia grupowa. Teoria i praktyka, Kraków 2006.

${ }^{35} \mathrm{Z}$ bodźca narracyjnego zrezygnowano na dwóch pierwszych i spotkaniu ostatnim. 
waną następnie analizie, musi ona charakteryzować się określonymi cechami, wspomnianymi powyżej, w części teoretycznej, jako definiujące narracje. Zdecydowano się uwzględniać, czy można w historii wskazać:

- bohatera (oceniano zatem, czy w podanej historii występował jasno wskazany bohater - mógł on zostać nieokreślony, kiedy np. stosowano w wypowiedzi stronę bierną, bez wcześniejszych odniesień co do osoby, możliwa była sytuacja pośrednia i wreszcie bohaterem mógł być autor wypowiedzi) $)^{36}$;

- posiadanie przez niego intencji ${ }^{37}$ (przy czym ponownie oceniano 3 możliwe sytuacje: kiedy to intencje nie występowały, w sytuacji pośredniej - były niejasne, wreszcie - zostały wskazane i można je było jednoznacznie z wypowiedzi wyprowadzić);

- wewnętrznie spójną historię ${ }^{38}$ (spójność odnosi się do obecności w wypowiedzi poszczególnych elementów struktury, przy czym dokonano uproszczenia Brunerowskiej9 propozycji: Prolog, Akcja, Zakłócenie, Restytucja/ Rewolucja, Koda i analizowano obecność (na 3 poziomach) wstępu, akcji, zakończenia, przy czym poziomy oznaczały kolejno: niemożliwa do wskazania obecność elementów strukturalnych, zaznaczone, wspomniane ich istnienie, wreszcie - pełne występowanie).

Analizie poddano 44 narracje, spełniające powyższe kryteria. W 39 przypadkach bohater był jednoznacznie określony, w 5 - owo określenie nie było jednoznaczne czy stałe; bohaterem w zależności od bodźca był rodzic lub rodzic i dziecko. W 27 historiach jasno wskazano intencje działającego podmiotu, w 17 - można było o niej wnioskować, lecz nie została jasno wskazana. Struktura historii jedynie w 5 przypadkach była w pełni zachowana, jednoznaczna i jasna, w pozostałych - dało się wyodrębnić części, ale zdarzały się niedokończone, zaznaczone tylko jednym słowem lub nie wszystkie były obecne. $Z$ analizy wyłączono narracje, które nie spełniały warunków w przynajmniej podstawowym stopniu (zatem, nie dało się wyodrębnić bohatera, jego intencji, czy struktury narracji).

Wyłonione narracje wielokrotnie analizowano treściowo, przy spełnieniu założenia wielokrotnego powracania do tekstu w poszukiwaniu wyłonionych kategorii i poddawaniu ich obecności weryfikacji - poprzez odniesienie do wyłonionych już znaczeń. Oczywiste jest, że każdy sposób analizy prowadzi do redukcji danych ${ }^{40}$, a jej kryteria wyznaczane są przez kategorie analizy,

${ }^{36}$ M. Zięba, M. Zatorski, Narracje oraz nadzieja podstawowa a wzrost posttraumatyczny po przeszczepieniu nerki, Psychologia Jakości Życia, 2013, 12, 2, s. 167-182.

${ }^{37}$ J. Trzebiński (red.), Narracja jako sposób rozumienia świata, s. 17-42.

${ }^{38}$ M. Zięba, M. Zatorski, Narracje oraz nadzieja podstawowa a wzrost posttraumatyczny, s. $167-182$.

${ }^{39}$ J. Bruner, Kultura edukacji, przekł. T. Brzostowska-Tereszkiewicz, Kraków 2006.

40 M. Miles, A.M. Huberman, Data Analysis, Sage Publications, 1994. 
wyłaniane w toku „kolejnych czytań”, czy odczytywań znaczeń. Przy analizie danych wykorzystano ogólne założenia analizy tematycznej ${ }^{41}$.

W analizie tematycznej (TA) można wyróżnić 6 etapów:

- zaznajamianie się z danymi - etap wspólny dla wszystkich badań jakościowych, w którym badacz po wielokroć zapoznaje się z materiałem, wnika weń, "umiejscawia” się w kontekście;

- tworzenie wstępnych kategorii - kiedy to badacz zaczyna dostrzegać interesujące go siatki pojęciowe; ustalane są wstępne wzorce rozumienia przez badanych świata, zatem dane są wstępnie kategoryzowane;

- poszukiwanie tematów - po wstępnej kategoryzacji badacz dociera do organizujących kategorie tematów czy zależności;

- analiza tematów, odnoszenie ich do wstępnych kategorii i do treści;

- w kolejnym kroku badacz definiuje odkryte tematy - poszukuje relacji między nimi, osadza w dostępnych teoriach;

- tworzenie raportu - poszukiwanie możliwie zrozumiałego, precyzyjnego i przekonującego sposobu na prezentację danych oraz swojego ich rozumienia ${ }^{42}$.

\section{Omówienie wyników badań}

Analizowane tutaj wypowiedzi można, oczywiście, umieszczać w wielu kontekstach i odczytywać na rozmaite sposoby. Sposób odczytania tekstów niewątpliwie jest zdeterminowany postawionym celem badań, umiejscawiającym $\mathrm{w}$ centrum ${ }^{43}$ problem funkcjonowania rodziców młodzieży z zaburzeniami psychicznymi. Ten kierunek analiz pozwolił wyprowadzić z tekstów kilka dominujących tematów, to jest: 1 - przebieg rozwoju dziecka z perspektywy rodziców, 2 - relacje między rodzicami a dzieckiem, a ponadto temat 3 tożsamości rodzicielskiej oraz 4 - radzenia sobie z zaburzeniem psychicznym syna czy córki ${ }^{44}$.

\section{Przebieg rozwoju dzieci oraz relacje między rodzicami a dzieckiem z perspektywy matek i ojców}

Przyglądanie się relacjom między rodzicami a dzieckiem z perspektywy tych pierwszych pozwala wskazać na obecną od początku życia dzieci

${ }^{41}$ M. Belotto, Data Analysis Methods for Qualitative Research: Managing the Challenges of Coding, Interrater Reliability, and Thematic Analysis, The Qualitative Report, 2018 23, 11, s. 2622-2633; V. Braun, V. Clarke, Using thematic analysis in psychology, Qualitative Research in Psychology 2006, 3, 77/101.

${ }^{42}$ V. Braun, V. Clarke, Using thematic analysis in psychology, Qualitative Research in Psychology, 2006, 3, s. 77-101.

${ }^{43} \mathrm{~J}$. Bruner, Kultura edukacji.

${ }^{44}$ Poniżej zostały przedstawione wypowiedzi wybrane. 
radość $\mathrm{z}$ ich pojawienia się na świecie oraz czułość wobec nich. I tak oto badani mówią:

B2: ...więc czekałam na nia dtugo

B3: ...(o mężu)...chodził po całej klatce szukać kogoś kto umie mleko rozrabiać w proszku

B4: Mówiłem, wiesz jaki to jest brzydal [śmieją się] Ale z takim, tak z sympatią, nie?

W ich pamięci zapisała się duma płynąca z prawidłowego przebiegu rozwoju dzieci, podkreślali radość związaną z przejawami eksplorowania świata czy tego, że potrafiły sygnalizować potrzeby.

B2: Płakała jak była głodna albo jak miała mokro. Szybko zaczęła przesypiać noce.

B2: ...patrzyła sie tymi oczami wszędzie, jakby wszystko wiedziała i wszystkich poznawała. I była idealnym niemowlakiem.

B4: ... zaczął tak, wydawać takie dźwięki, charakterystyczne, tak mruczał po prostu $i$ wtedy dopiero się zorientowała, że jest nieubrany, że się wyziębił (...)

B1: Życie sielskie anielskie.

B4: Dziesięć punktów miat, nie? W skali Apgar.

B2: Ale przybierała bardzo ładnie na wadze. Później jak już można było ocenić te wszystkie postepy, siadania, siadanie i tam chwytanie. No wszystko, wszystko jak gdyby było, było prawidłowo.

B8: Jako niemowlę byt, był pogodnym dzieckiem. Był przeze mnie bardzo oczekiwanym.

W większości narracji można zatem dostrzec, że wczesny okres rozwoju dziecka rodzice wspominają jako raczej wypełniony radością i dumą niż troskami.

Niektórzy zaznaczają, że pojawiały się wtedy oznaki tego, że coś może będzie w przyszłości „nie tak”, „pomruki nieba przed burzą”, ale wówczas nie zostały przez nich oczywiście właściwie zinterpretowane. Natomiast nabrały nowego znaczenia w kontekście ujawnionego już zaburzenia. Ujawniło się to w odpowiedziach badanych, na prośbę dotyczącą opowiedzenia wspomnienia z porodu. Historie mają w kilku przypadkach typową powtarzalną konstrukcję: wszystko szło dobrze, idylliczne oczekiwania, następnie komplikacja akcji, rozwiązana szczęśliwie, ale obecnie interpretowana jako zapowiedź późniejszych problemów, a przynajmniej nie odczytany komunikat wysyłany (przez los? Boga? naturę?) do „naiwnych” rodziców o tym, że rodzicielstwo jest $\mathrm{w}$ istocie trudne. I tak: 
B2: Kiedy, kiedy ja właściwie zaczęłam mdleć już, mdleć już po prostu. Zrobiono mi znieczulenie. E, no nic jak gdyby się nie, dalej rozwarcie po prostu nie postępowato. Dwa razy właściwie już później no ustała akcja, akcja serca. I wtaściwie w takim trybie przyspieszonym zdecydowano o cesarskim cięciu. (...)

B1: Jak się urodzit, e, to e, no to byt podwójnie ta zapętlony pepowina. Byt już cały siny $i$ tak dalej, więc, no to było takie, no do tej pory tak troche jest mi z tym źle.

B6: Ja się bardzo ucieszyłem. Poród, no, przebiegat chyba normalnie. Tak mówię chyba, ale tak, po urodzeniu przestat na moment oddychać i zgasty światta w szpitalu. Prąd wyłaczyli. Lekarze spojrzeli na siebie.

Obecnie niektórzy nadają symboliczne znaczenie tamtym zdarzeniom. Takie nie zawsze wyrażone interpretacje były też podchwycone przez grupę, co otworzyło pole do kolejnych wyjaśnień:

B2: Później, jak się właśnie zaczęty takie jakieś te problemy właśnie z tym jej spaniem, czy w okresie dojrzewania. I rozmawiałam z psychologiem. Powiedziano mi, że to sa rzeczy, których nie da się udowodnić $i$ stwierdzić, natomiast jej zaburzenia osobowości moga mieć przyczyny właśnie w tym trudnym porodzie, kiedy mogło dojść do jakichś uszkodzeń właśnie, mikro uszkodzeń w systemie nerwowym.

B5: To było dziwne przė̇ycie.

Wydaje się, że powyższe interpretacje są pochodną znaczenia, jakie zaburzenie psychiczne adolescenta ma dla rodziców ${ }^{45}$. Jest jednym $\mathrm{z}$ ich najważniejszych życiowych doświadczeń, zmienia percepcję przeszłości w tym kierunku, by dało się odczytać w jej przestrzeni (pomimo tego, że po czasie i raczej jako dowód własnej wówczas niskiej świadomości) owo znaczenie z symbolicznych zdarzeń. Narracje są przesycone określonym klimatem emocjonalnym ${ }^{46}$. W narracjach dotyczących całego życia lub zdarzeń dla jego przebiegu istotnych, przejścia od emocji pozytywnych do negatywnych są typowe: tu też idylliczna atmosfera dzieciństwa zostaje zakłócona zdarzeniami nasyconymi grozą, następnie nieświadomy bohater wraca do radosnego przeżywania rzeczywistości.

Większość osób dostrzega presymptomy zaburzeń czy też pierwsze oznaki problemów w okresie średniego dzieciństwa dziecka, choć oczywiście „oznaki” te mogły nie wiązać się z niczym więcej, jak typowe dla okresu szkolnego problemy. I tak na przykład:

B5: Wymagało to [nauka szkolna - HK] bardzo wielu ćwiczeń $i$ spędzenia czasu na naprawdę żmudnych ćwiczeniach razem ze mną. Ukończenie szkoły podstawowej

\footnotetext{
${ }^{45}$ H. Kubiak, Problemy rodziców adolescentów, s. 83-94.

${ }^{46}$ P. Oleś, Psychologia człowieka dorosłego.
} 
tė் z trudem. Czyli, cała szkoła podstawowa była naprawde, ciagle jacyś dodatkowi nauczyciele. E, następnie przejście do gimnazjum. Do takiej zwykłej państwowej szkoły. Zaliczył pierwszy rok. E, gdzie właściwie było ultimatum, że albo go przenosimy, albo zostaje ponownie w tej samej klasie. Tam były incydenty, właśnie jakimiś prezentami dość drogimi. [Kosztownymi.] Kosztownymi. E, nastęnie sytuacja była taka, że przenieśliśmy go do szkoły prywatnej. (...) Poznał dziewczyne, która była tak samo, bym powiedziała, w kłopotach jak i syn. Więc pojawity się dopalacze.

B8: Nie było jeszcze problemów w nauce $i$ w ogóle zawsze o nim mówiono, że nie jest rozwinięty pod względem intelektualnym. Natomiast, problemy jego dotyczyty emocjonalności. Tu w klasach cztery-sześć y, nawet wiem, że nauczycielka jedna powiedziała, on najlepiej bawiłby się sam. Czyli była już taka, trochę izolacja. I do, do czasów gimnazjum miat tylko jednego takiego bliskiego przyjaciela. Inni to, to byli tacy, nie potrafit się zaprzyjaźnić z wieloma kolegami, co nas troche niepokoiło. W związu tam z jego problemami chodziliśmy też do pani psycholog, pamiętam. Co tutaj jest ważne, że poradziła nam ona i w ogóle tak, że y, działaliśmy poprzez kary $i$ nagrody.

Z obecnej perspektywy trudno stwierdzić, czy te i podobne problemy, które pojawiały się u dzieci były przejawem narastających trudności, czy wiązały się z typowymi dla przebiegu rozwoju kłopotami, które nabrały innego sensu w obliczu późniejszych wydarzeń.

Można zatem wnioskować, że rodzice przejawiają tendencję do poszukiwania określonych sensów czy znaczeń w zdarzeniach, które kiedyś wydawały się neutralne. Może to wiązać się z powszechną ludzką potrzebą nadawania sensu zdarzeniom, doświadczeniom, szerzej - życiu. Być może, ta refleksyjność wzrosła też ze względów rozwojowych - okres środkowej dorosłości sprzyja namysłowi, który ma prowadzić do wniosków dotyczących całego życia $^{47}$.

\section{Relacje rodzice-dziecko. Tożsamość rodzicielska}

Ów pogłębiony namysł dotyczy również relacji między rodzicami a dzieckiem. W teraźniejszości są one przez rodziców analizowane, bywają przestrzenią poczucia winy i myśli dotyczących tego, co można było zrobić inaczej. Rodzice zadają sobie pytanie, czy cokolwiek w ich zachowaniu mogło odwrócić bieg wydarzeń. W okresie wczesnego dzieciństwa rodzice nie przejawiali takiego niepokoju, który najwyraźniej jest skutkiem zdiagnozowania

${ }^{47}$ M. Olejnik, Średnia dorostość, [w:] Psychologia rozwoju człowieka, red. J. Trempała, Warszawa 2012 , s. 312-325. 
zaburzeń psychicznych u dziecka. Relacje w przeszłości nie były obejmowane tak pogłębioną refleksją.

B2: No nie, były momenty, że byłam nerwowa, złościłam się i tak dalej.

B5: Mieliśmy incydent latem, gdzie mąż, pracowat u męża syn. E, no poszło na noże, jak to się mówi po męsku. Syn zostat sam w domu. Y, ja wtedy wyjechałam. Maż̇ stwierdzit, koniec kropka, musisz sobie sam radzić. Przyszło załamanie [w relacji dopisek HK].

Relacje te wymagają od rodziców, jak wspomniano, więcej świadomej pracy, refleksji w miarę narastających problemów z zachowaniem nastolatka i po pojawieniu się diagnozy. Dzieje się tak również dlatego, że wystąpienie zaburzenia psychicznego u nastolatka bywa punktem prowadzącym do kryzysu egzystencjalnego jego rodziców ${ }^{48}$. Duże natężenie emocji, zakwestionowanie dotąd oczywistych aksjomatów, otwarcie na doświadczenie ${ }^{49}$ powodują, że rodzice szukają różnych dróg sprawowania swojej roli wobec dzieci, co zmienia nie tylko sytuację zewnętrzną, ale też ich samych.

B5: Były momenty, kiedy, znaczy ludzie, chwytałam się czasami różnych rzeczy po to, żeby coś albo wyłuskać z niego, albo coś zmienić. Tak naprawdę nie wiemy, co zrobić. Byty momenty, kiedy byt sam. E, kiedy widziałam, że to już po prostu, wróciliśmy, opiekujemy się tak naprawdę wówczas, kiedy jeździłam, sprawdzałam czy wstał. Czy jest w stanie wyjść na dwór, tak? Z córka na zamianę wychodzityśmy z nim na dwór. (...) Po prostu robię to. I tak naprawdę szukam rozwiazania. Bo ja się po prostu w pewnych momentach zaczynam wyłaczać, nie? Nie wiem, czy to jest dobre czy to jest złe, ale się wyłaczam.

\section{Tożsamość rodzicielska}

W wyniku przeżywania trudnych sytuacji, różnego ich wartościowania, pracy nad sobą, pojawiają się nowe treści odnośnie rodzicielskiej tożsamości badanych. I tak mówią na przykład.

B6: No, bycie ojcem jest puszczanie na pastwe losu. I kiedy się podjąem nauki ptywania, (Mhm) bo też zrobiliśmy taka nauke ptywania dla powiedzmy catej wsi (Mhm). To, to było tak właśnie, że rzucenie na pastwę losu.

Odpowiedź na nawiązanie prowadzącej:

B5: (...) bycie mama to bycie w kontakcie.

${ }^{48}$ H. Kubiak, M. Zięba, Grupa rozwoju osobistego, s. 327-345.

${ }^{49}$ B. Jacobsen, The life crisis in a existential perspective: can trauma and crisis be seen as an aid personal development? Journal of Existential Analysis, 2006, 17, 1, s. 39-54. 
B5: I faktycznie tak jest, jak tracę kontakt, to bardzo źle się czuję (Mhm). Bardzo mnie to dyskomfortuje, że na przykład nie odzywaja się moje dzieci. Tego muszę się nauczyć. Jak mówię dzwonił pięć razy (...) Oddzwaniam, mówię co się stało? On mówi, wiesz mamo, już nieważne (Mhm). I następnie nie mogłam (...) się z nim zdzwonić już do końca tego dnia. Więc mój stres podszedt pod tak zwany już (niejasne) sto procent. I zdałam sobie sprawę, że ten kontakt jest dla mnie tak ważny, że naprawdę dla mnie to byto ogromne przeżycie. Przyptaciłam bólem głowy e-ce-te i tak dalej.

B8: Że bycie matka to uleganie. Y, no, powiem, że czasami wtaśnie tak ulegam, a potem jak syn się nie zachowa tak, jak bym oczekiwała tego, że coś mu tam dałam, a on jednak zrobit i tak po swojemu. Potem jestem zła na siebie.

Jeden z badanych mówi przejmująco:

B4: ... dla mnie bycie rodzicem znaczy bycie samotnym, zranionym i dotkniętym, (...) bo dzisiaj byto tak, że pracowatem w domu i moja córka tam o którejś godzinie zapytała czy, czy może sobie zamówić coś na o, na obiad, nie? Ja mówię, że wiesz co, ja wtaśnie idę teraz po obiad dla wszystkich do Tesco, bo tam się kupuje po prostu gotowe potrawy $i$ ci kupię kurczaka z rożna, albo co tam jeszcze będziesz chciała, $z$ tego. A ona mówi, nie tato, ja nie jadam w Tesco (Mhm). No, ja mówię, no to jak nie jadasz w Tesco, to ja ci dam te pieniadze, które bym wydał w Tesco, a resztę prosze dołóz sobie ze swoich $i$ sobie kupisz co będziesz chciała. No i tam się zajątem praca $i$ w pewnym momencie się zorientowałem, że mojej córki po prostu nie ma w domu. Mimo że jest tam na antybiotykach $i, i$ w ogóle jest chora, przeziębiona, tam już kolejny raz.

Ponownie, nie sposób rozstrzygnąć, które treści w tożsamości rodzicielskiej są wynikiem, i w jakim stopniu, wystąpienia zaburzenia u dziecka ${ }^{50}$. Można jedynie założyć, że przejście przez wiele skrajnie trudnych sytuacji wyzwala bardzo różne reakcje: mechanizmy radzenia sobie, umiejętność odpuszczania lub uruchamia rezygnację, czy poczucie bycia zranionym i odsuniętym. W myśleniu o sobie, jako o rodzicu, mieszczą się najprawdopodobniej skrajnie różne treści, ale w odpowiedzi na pytanie: Co znaczy dla Ciebie bycie rodzicem, uruchomiły się te, które były związane z ostatnimi wydarzeniami albo myślami, czy uczuciami przeżywanymi przez osobę.

\section{Bilans życiowy - wzrost posttraumatyczny}

Kolejny temat obecny $\mathrm{w}$ wypowiedziach rodziców stanowił znaczenia zaburzenia obecnego u ich dzieci, z rodzicielskiej perspektywy. Zadano im

${ }^{50}$ Dla celów niniejszego tekstu nie ma to znaczenia, natomiast ma dla rodziców; te pytania były przez nich stawiane, dlatego o tym piszę. 
pytanie: w jaki sposób biegłoby ich życie, gdyby nie zaburzenie psychiczne dziecka. Pytanie to uruchomiło refleksję dotyczącą biegu życia, istotnych z punktu widzenia wartości. Zaburzenie dziecka wytrąca rodziców z pewnych automatycznych reakcji, wymaga od nich zwiększonej świadomości, także w odniesieniu do siebie. Skłania do dokonania życiowego bilansu. Jakkolwiek zazwyczaj towarzyszy on okresowi późnej dorosłości i ma stanowić podsumowanie całego życia ${ }^{51}$, to jednak zdarza się, że jest prowadzony w odniesieniu do konkretnej sytuacji, kontekstu ${ }^{52}$. W wypowiedziach rodziców można wyróżnić kilka rodzajów bilansu - egzystencjalny, odnoszący się do wartości, ale także bilans otwarcia - „polegający na sprawdzeniu, co wynika z doświadczenia przeszłości dla realizacji nowych celów i dążeń" ${ }^{\prime \prime}$. Można założyć, że odpowiedzi na pytanie: „jak wyglądałoby Twoje życie, gdyby nie zaburzenie psychiczne u dziecka", są wyrazem pragnień i celów, które są najczęściej stały się lub zostały uświadomione - ważne dla badanych. Według P. Olesia, analizy składające się na bilans zawierają w sobie wieloaspektową ocenę własnej sytuacji - ocenę prawidłowości (odniesienie do normatywnego stylu życia ${ }^{54}$, które toczyłoby się, jak toczy u innych ludzi nie dotkniętych zaburzeniem), ocenę wartości oraz sensu (por. niżej) oraz ocenę szans (odniesienie do własnych możliwości istotnych dla spełniania celów).

B1: W tej chwili właśnie, w ostatnim, w ostatnim czasie e, tak zaczęłam też bardziej zwracać uwage na swoje odczucia i na siebie.

Rodzice są świadomi, że zaburzenie jest „zachłanne” - to jest wymusza od nich koncentrację na nim, $\mathrm{w}$ przeciwnym razie zajmowaliby się czym innym.

B1: W tym wieku, kiedy on ma dwa/jest $w$ drugiej klasie i może byśmy się wszyscy bardziej skupili na tym (Mhm). A nie tylko się kręcili wokót, wokót tego, tej choroby, nie? No i też żałujęże syn (...) nie wykorzystuje wszystkich możliwości, którymi dysponuje.

Niektórzy wskazują jednak, że obecność zaburzenia w ich życiu prowadzi do przewartościowania pewnych spraw, pozwala przyjąc inną hierarchię wartości. Można zatem podsumować, w myśl koncepcji wzrostu posttraumatycznego, że "straty tworzą coś wartościowego" 55 , a przynajmniej - że może się tak stać.

${ }^{51}$ P. Oleś, Psychologia człowieka dorosłego.

52 Tamże.

${ }^{53}$ Tamże.

${ }^{54}$ Tamże.

${ }^{55}$ R. Tedeschi, L. Calhoun, Podejście kliniczne do wzrostu po doświadczeniach traumatycznych, [w:] Psychologia pozytywna w praktyce, przekł. J. Kowalczewska, J. Radzicki, J. Suchecki, M. Szuster, A. Tarłowski, red. naukowa J. Czapiński, Warszawa 2007, s. 230-248. 
B4: Ale może powiem, powiem troche paradoksalnie o tym, co by sie na gorsze zmienito (Mhm). Bo przez tę chorobę syna myśmy, wydaje mi się, złapali tak dobry kontakt ze sobą, jak nigdy dotąd. Ale to daje taka, no niesamowita, satysfakcje, nawet to, to nie można tego mierzyć kategoria, w kategoriach satysfakcji. Ale tak, no taka radość, nie? (Mhm) Taką czystą radość że, że, że właśnie ja przestałem, na jakiś czas, być takim złym coach'em, powiedzmy, dla niego. (...) No, także tu dostrzegam bardzo dużo pozytywów.

Dla procesu posttraumatycznego wzrostu charakterystyczne są paradoksy dotyczące zwiększonej podatności na zranienie i zarazem odporności, na skutek nie tyle przeżycia traumy, co sposobów wydobywania się z niej, pracy nad sobą ${ }^{56}$. Niekiedy ten proces pozwala dostrzec piękno życia, w chwili zakwestionowania aksjomatów, na którym się ono opiera ${ }^{57}$. Ilustruje to wypowiedź badanej:

B2: I tak tė̇ pomyślałam sobie, że właściwie to byłoby chyba, bardzo y, szczęśliwe to to, to życie, gdyby nie, gdyby nie to, co się przydarzyło z córka (Mhm). Że i, jak gdyby idac tym torem, pomyślałam sobie, że może ta cała historia była, jest po to, żeby uzmysłowić sobie jak, jak dużo było tych chwil, kiedy nie umiałam docenić tego co miałam. Jak wiele właśnie takich chyba przeoczyłam tych chwil, kiedy właściwie miałam wszystko (...). Ciagle dzieci brzydkie robiły nie wiem babki, albo kółko graniaste byto zbyt kurczę kanciaste, tak? (...)

B5: Całkiem inne [byłoby życie - dopisek HK]. Mimo wszystko. Myślę, że nie zetknęlibyśmy się z tym całym światem. Z tymi informacjami, które dostaliśmy, czyli takie błogie, bym powiedziała. Lekkie, przyjemne właśnie, bez cierpienia. (...) No to, to jest tak, że to co przeżywamy nas wzbogaca. Co by nie było, tak jest. Także te granice dzięki synowi utrzymałam. Tak, czyli na pewno. Czasami sobie mówię, dziękuje mój synu, tylko dlaczego masz cierpieć. I tak chyba wolałabym zostać w poprzedniej sytuacji.

B2: I nagle trzeba znaleźć w sobie właśnie jakieś pokłady cierpliwości, pokłady jakiejś umiejętności, negocjacyjne, bo to się okazuje, że to nie jest relacja, tylko właśnie, ja-córka. Córka-mąż. Córka-syn.

Kolejnym paradoksem wydaje się może, że pomimo zwiększonej odporności, innej, bardziej uświadomionej hierarchii wartości i sile, które są wynikiem traumy, większość osób wolałaby przez tę sytuację nie przechodzić, ponieważ korzyści i wzrost są związane nie tylko z własnym cierpieniem, ale i cierpieniem dziecka, które trudno przyjąć. Widać to w poprzedniej wypowiedzi, choć także inna osoba mówi, że:

\footnotetext{
56 Tamże.

57 B. Jacobsen, The life crisis in a existential perspective, s. 39-54.
} 
B3: Ja, ja nie lubię tych jego stanów właśnie takiego obniżonego nastroju. (...) Bo ja po prostu widzę, że on cierpi. On nie śpi, on sie strasznie zamartwia szkoła, wszystkim się zamartwia wtedy. I ja po prostu jakby z nim to przeżywam. (...) Także nie potrafię znaleźć, znaczy, nie potrafię w tym znaleźć jakiegoś plusu.

B8: No, gdyby nie ta choroba, to chyba żyłoby się jednak lżej, tak? (Mhm). Tak myśle. Nie byłoby tak ciężko z tym wszystkim.

Wspomniane dwie postawy: radości z własnego wzrostu, zmiany, świadomości oraz żal dotyczący trudności przeżywanych przez całą rodzinę splatają się niekiedy w jednej osobie, nawet w jednej chwili.

\section{Podsumowanie}

W biografii rodzica wystąpienie u jego dziecka zaburzeń psychicznych jest znaczącym doświadczeniem. Trudno je wpisać w system przekonań o świecie, o sobie i ludziach. Wymaga zatem przekroczenia automatycznych reakcji i autorskiego się do niego odniesienia ${ }^{58}$. Kiedy zaburzenie dotyczy adolescenta, jego rodzice zmuszeni są poszukiwać indywidualnych sposobów wspierania dziecka na drodze ku dorosłości, w stopniu większym i okolicznościach trudniejszych, niż ma to miejsce w historii rodzin z nastolatkami bez problemów psychicznych.

Grupa wspierająca rodziców stanowiła przestrzeń, w której uczestnicy mogli towarzyszyć sobie wzajemnie, konstruować i słuchać narracji poświęconych rodzicielstwu, rodzinom, dzieciom. Mogło to stanowić ważny element procesu rekonstruowania rodzicielskiej tożsamości. Narracje, a zatem opowiadanie innym ludziom ${ }^{59}$ o sobie porządkuje zdarzenia i sprzyja nadawaniu im znaczeń. $W$ opisywanej grupie narracje występowały $\mathrm{w}$ formie intrapsychicznej - związanej z układaniem treści i interpersonalnej, związanej z ich komunikowaniem ${ }^{60}$. Służyły rozwojowi osób w obszarze ich tożsamości i obszarze relacji. W toku tego procesu szczególnie ważne ${ }^{61}$ były emocje. Występowały w całej gamie i pełnym spektrum nasilenia.

Owe współwystępowanie różnych, czasem przeciwstawnych, wrażeń i emocji doświadczyła również osoba prowadząca grupę, współodczuwając z rodzicami młodzieży radość i smutek. Radość ta płynęła ze wspomnianych powyżej dostrzeżonych wartości, związanych z posttraumatycznym wzro-

${ }^{58}$ K. Obuchowski, Galaktyka potrzeb, Poznań 2002.

${ }^{59}$ Lub sobie, ale $\mathrm{w}$ przypadku opisywanej grupy istnieli słuchacze zewnętrzni.

${ }^{60}$ E. Soroko, Określanie wad $i$ zalet metod generowania autonarracji, [w:] Badania narracyjne w psychologii, red. M. Straś-Romanowska, B. Bartosz, M. Żurko, Warszawa 2010.

${ }^{61}$ Poza treściami opisanymi w części: Omówienie wyników. 
stem oraz wiązała się z siłą płynącą ze wspólnoty, którą grupa stworzyła ${ }^{62}$. Smutek wynikał ze współodczuwania cierpienia, ale wiązał się też z egzystencjalną refleksją dotyczącą zmienności losu i konieczności poddania się jemu w wielu sytuacjach.

\section{BIBLIOGRAFIA}

Belotto M., Data Analysis Methods for Qualitative Research: Managing the Challenges of Coding, Interrater Reliability, and Thematic Analysis, The Qualitative Report, 2018 23, 11.

Braun V., Clarke V., Using thematic analysis in psychology, Qualitative Research in Psychology, 2006, 3.

Bruner J., Actual minds, possible worlds, Harvard University Press, Cambridge, Mass. 1986.

Bruner J., Kultura edukacji, przekł. T. Brzostowska-Tereszkiewicz, Towarzystwo Autorów i Wydawców Prac Naukowych „Universitas”, Kraków 2006.

Cieciuch J., Między przedmiotem a metodą. Watpliwości zwiąane z koncepcją tożsamości narracyjnej McAdamsa, [w:] Psychologia narracyjna. Tożsamość, dialogowość, pogranicza, red. E. Dryll, A. Cierpka, Wydawnictwo Eneteia, Warszawa 2011.

Denzin N., Lincoln Y., Metody badań jakościowych, przekł. K. Podemski, Wydawnictwo Naukowe PWN, Warszawa 2009.

Frankl V., Człowiek w poszukiwaniu sensu, przekł. A. Wolnicka, Wydawnictwo: Jacek Santorski, Warszawa 2011.

Hermans H., Self-Narrative as Meaning Construction: The Dynamics ol Selflnvestigation, Journal of Clinical Psychology, 1999, 55(10).

Howard G., Culture tales: A narrative approach to thinking, cross-cultural psychology, and psycho therapy, American Psychologist, 19991, 46(3).

Jacobsen B., The life crisis in a existential perspective: can trauma and crisis be seen as an aid personal development? Journal of Existential Analysis, 2006, 17, 1.

Kubiak H., Edukacja emocjonalna adolescentów - program profilaktyczny ukierunkowany na wspomaganie zdrowia psychicznego adolescentów, Kultura - Społeczeństwo - Edukacja, 2016, 2(10).

Kubiak H., Problemy rodziców adolescentów z zaburzeniami psychicznymi, [w:] W trosce o macierzyństwo, red. E. Włodarczyk, Wydawnictwo Naukowe UAM, Poznań 2017.

Kubiak H., Zięba M., Grupa rozwoju osobistego dla młodzieży z zaburzeniami psychicznymi sprawozdanie z zajęć, Studia Edukacyjne, 2015, 36.

McAdams D., Personal narratives and the life story, [w:] Handbook of personality: Theory and research, red. L. Pervin, O. John, (II wyd.), Guilford Press, Nowy Jork 1999.

McAdams D.P., The Psychology of Life Stories, Review of General Psychology, 2001, 5, 2.

Miles M., Huberman A.M., Data Analysis, Sage Publications, Beverly Hills 1994.

Miller A., Rathus J., Linehan M., Dialektyczna terapia behawioralna nastolatków z tendencjami samobójczymi, przekł. J. Okuniewski, Wydawnictwo Uniwersytetu Jagiellońskiego, Kraków 2011.

Obuchowski K., Galaktyka potrzeb, Zysk i S-ka Wydawnictwo, Poznań 2002.

Olejnik M., Średnia dorosłość, [w:] Psychologia rozwoju człowieka, red. J. Trempała, Wydawnictwo Naukowe PWN, Warszawa 2012.

${ }^{62}$ I. Yalom, M. Leszcz, Psychoterapia grupowa. 
Oleś P., Dialogowe Ja: zarys teorii, inspiracje badawcze, ciekawsze wyniki, [w:] Dialog z samym soba, red. P. Oleś, M. Puchalska-Wasyl, Wydawnictwo Naukowe PWN, Warszawa 2011.

Oleś P., Psychologia człowieka dorosłego, Wydawnictwo Naukowe PWN, Warszawa 2011.

Oleszkiewicz A., Senejko A., Psychologia dorastania, Wydawnictwo Naukowe PWN, Warszawa 2013.

Rosner K., Narracja, tożsamość i czas, Wydawnictwo Universitas, Kraków 2003.

Sarbin T. (red.), Narrative psychology: The storied nature of human conduct, Praeger, New York 1986.

Soroko E., Poziom autonarracyjności wypowiedzi i użyteczność wybranych sposobów ich generowania, Wydawnictwo Naukowe UAM, Poznań 2007.

Soroko E., Narracja jako tekst kultury czy sposób komunikowania się, Poznań 2007 (praca doktorska).

Soroko E., Określanie wad i zalet metod generowania autonarracji, [w:] Badania narracyjne w psychologii, red. M. Straś-Romanowska, B. Bartosz, M. Żurko, ENETEIA Wydawnictwo Psychologii i Kultury, Warszawa 2010.

Tedeschi R., Calhoun L., Podejście kliniczne do wzrostu po doświadczeniach traumatycznych, [w:] Psychologia pozytywna w praktyce, przekł. J. Kowalczewska, J. Radzicki, J. Suchecki, M. Szuster, A. Tarłowski, red. naukowa J. Czapiński, Wydawnictwo Naukowe PWN, Warszawa 2007.

Trzebiński J. (red.), Narracja jako sposób rozumienia świata, Gdańskie Wydawnictwo Psychologiczne, Gdańsk 2002.

White M., Epston D., Narrative means to therapeutic ends, WW Norton \& Company, 1990.

Yalom I., Leszcz M., Psychoterapia grupowa. Teoria i praktyka, Wydawnictwo Uniwersytetu Jagiellońskiego, Kraków 2006.

Zięba M., Zatorski M., Narracje oraz nadzieja podstawowa a wzrost posttraumatyczny po przeszczepieniu nerki, Psychologia Jakości Życia, 2013, 12, 2. 